\title{
Individual niche trajectories in nesting green turtles on Rocas Atoll, Brazil: an isotopic tool to assess diet shifts over time
}

\author{
Karoline Fernanda Ferreira Agostinho ${ }^{1}{ }^{\circledR}$, Leandro Rabello Monteiro ${ }^{1 \oplus} \&$ \\ Ana Paula Madeira Di Beneditto ${ }^{1 *}$ ()ㅜ \\ ${ }^{1}$ Universidade Estadual do Norte Fluminense Darcy Ribeiro, Centro de Biociências e Biotecnologia, \\ Laboratório de Ciências Ambientais, Av. Alberto Lamego 2000, CEP 28013-602, Campos dos Goytacazes, RJ, \\ Brasil. \\ *Corresponding author: Ana Paula Madeira Di Beneditto, e-mail: anapaula@uenf.br
}

AGOSTINHO, K.F.F., MONTEIRO, L.R., DI BENEDITTO, A.P.M. Individual niche trajectories in nesting green turtles on Rocas Atoll, Brazil: an isotopic tool to assess diet shifts over time. Biota Neotropica 21(1): e20201099. https://doi.org/10.1590/1676-0611-BN-2020-1099

\begin{abstract}
In this study, multi-tissue (yolk and carapace) stable isotope analysis was used to assess individual isotopic niche trajectories of nesting green turtles on Rocas Atoll, off northeastern Brazil, and to reveal a diet shift in the temporal dimension. The diet trajectories of individual green turtles were highly directional, with a stronger component towards decreasing values of $\delta^{15} \mathrm{~N}$ from carapace to yolk. When the green turtles are in their foraging sites (temporal window measured by the yolk samples), they are more herbivores. Conversely, in a broader temporal window, the green turtles demonstrate a carnivore-omnivore strategy, such as represented by heavier $\delta^{15} \mathrm{~N}$ values in the carapace. This finding confirms a temporal diet shift. This is the first study that applies trophic niche trajectories for sea turtles, adding a new isotopic tool to understand the trophic ecology of these migrant animals. Keywords: Chelonia mydas; adult females; stable isotopes; trophic ecology; Atlantic Ocean.
\end{abstract}

\section{Trajetórias de nicho individual em tartarugas verdes do Atol das Rocas, Brasil: uma ferramenta isotópica para verificar trocas de dieta ao longo do tempo}

\footnotetext{
Resumo: Neste estudo, a análise de isótopos estáveis em múltiplos tecidos (vitelo e carapaça) foi usada para avaliar as trajetórias individuais de nicho isotópico de tartarugas verdes em nidificação no Atol das Rocas, nordeste do Brasil, e para revelar uma mudança de dieta na dimensão temporal. As trajetórias individuais da dieta de tartarugas verdes foram altamente direcionais, com um componente mais forte na direção de valores decrescentes de $\delta^{15} \mathrm{~N}$ da carapaça ao vitelo. Quando as tartarugas verdes estão em seus locais de forrageamento (janela temporal medida pelas amostras de vitelo), elas são mais herbívoras. Por outro lado, em uma janela temporal mais ampla, as tartarugas verdes demonstram uma estratégia carnívora-onívora, representada por valores mais elevados de $\delta^{15} \mathrm{~N}$ na carapaça. Os resultados confirmam uma mudança temporal na dieta. Este é o primeiro estudo que aplica trajetórias de nicho trófico para tartarugas marinhas, adicionando uma nova ferramenta isotópica para entender a ecologia trófica desses animais migrantes.

Palavras-chave: Chelonia mydas; fêmeas adultas; isótopos estáveis; ecologia trófica; Oceano Atlântico.
} 


\section{Introduction}

The green turtle (Chelonia mydas Linnaeus, 1758) is the only sea turtle species known to be herbivore after the individuals' recruitment from oceanic to coastal waters (Bjorndal 1997). However, the contribution of animal matter in its diet can be variable, as demonstrated in the last decade (e.g., Burkholder et al. 2011; Carman et al. 2012; Veléz-Rúbio et al. 2016; Di Beneditto et al. 2017; Fukuoka et al. 2019). Adult sea turtles are true migrants, moving between foraging and breeding sites thousands of kilometers apart. Comparing satellite telemetry data, Shimada et al. (2020) showed that fidelity to specific foraging sites following breeding migrations is common across several sea turtles species. For the green turtle, the authors stated high and longterm fidelity to specific foraging sites, with feeding activity happening during the migration to-and-from the breeding sites.

Stable isotopes are chemical proxies applied as a tool to analyse animals' trophic niches because they allow inferences on food resource use over many temporal scales (Newsome et al. 2007). The stable isotope of carbon $\left(\delta^{13} \mathrm{C}\right)$ represents the food resource origin, with more enriched values (less negative) in coastal than in oceanic waters and in benthic than in pelagic environments. The stable isotope of nitrogen $\left(\delta^{15} \mathrm{~N}\right)$ tracks the animals' trophic position and it is more enriched at higher trophic levels, i.e. carnivore and omnivore consumers usually have more enriched $\delta^{15} \mathrm{~N}$ values in their tissues than herbivore consumers (Fry 2008).

Since each tissue has a specific metabolic rate, its turnover time, i.e. the time within which stable isotopes in tissues are replaced by stable isotopes derived from the food sources, is different (Auerswald et al. 2010). Keratinous tissues, like hair and carapace scutes, are metabolically inert and maintain an isotopic record from the location where they were synthesized, representing the dietary information over a longer period (e.g. several months or years) (Hobson 1999). In metabolically active tissues, such as liver, this information refers to a shorter time, such as a few weeks (Hobson 1999). The vitellogenesis process of sea turtles happens 4 to 6 months before the female's migration to the breeding site, when she is still at the feeding site (Rostal et al. 1998). Thus, the egg yolk represents the dietary information in a narrower temporal window when compared to carapace scutes. By comparing the isotopic profile from different tissues, it is possible to analyse the temporal consistency of individual diet through isotopic niche trajectories (Costa-Pereira et al. 2019). The assumption is that individuals with temporally consistent diets have more similar isotope values across tissues than individuals with temporally variable diets (Martínez del Rio et al. 2009).

Individuals from the same population do not necessarily have temporally consistent foraging strategies, undergoing diet shifts over time, while others may have a more constant diet (Bearhop et al. 2004; Martínez del Rio et al. 2009). Fukuoka et al. (2019) demonstrated by stable isotope analysis and biologging experiments the seasonal diet shift in a juvenile green turtle population from Japanese Pacific waters. The temporal dimension of individual foraging strategies allows for an understanding of habitat use as a whole (Costa-Pereira et al. 2019), which is especially important for true migrant species, such as the sea turtles.

In this study, multi-tissue (yolk and carapace) stable isotopes were used to assess the consistency of trophic niches of nesting green turtles over time. This approach was adapted from Costa-Pereira et al. (2019), whose study with dozens of populations and hundreds of individuals from tropical frogs' species demonstrated the reliability of the trophic niche trajectories to measure the trophic consistency of individuals in a temporal scale. The carapace represents a comprehensive assimilation, integrating diet from several months to years ago, whereas the yolk represents the food assimilation from a few months before oviposition, while the nesting females are still at the feeding sites. If the hypothesis of a consistent dietary pattern over time is supported, yolk and carapace isotope values will be similar, and variation in the individual trophic niche trajectories (lengths and angles) is not expected to differ from a random pattern of changes.

\section{Material and Methods}

\section{Sampling}

The sampling of green turtles on Rocas Atoll ( $03^{\circ} 51^{\prime} \mathrm{S}$; $\left.33^{\circ} 49^{\prime} \mathrm{W}\right)$ was authorized by the Brazilian Government by the license number 59809. This area is the second largest nesting site for the green turtles in Brazilian waters (Bellini et al. 2013). It is the only atoll in the South Atlantic Ocean, with $7.5 \mathrm{~km}^{2}$ and located $266 \mathrm{~km}$ off the northeastern Brazilian coast. Rocas Atoll is a marine biological reserve; therefore, a pristine area. Bellini et al. (2013) conducted a comprehensive survey to monitor the nesting females in this site from 1990 to 2008. The nesting season occurs from December (beginning, with few nests) to May, with peak from February to April. The average number of nesting females per season is 73 , with five nests per individual. The mean remigration period is 3.5 years. The authors estimated that 255 reproductively active females nested on the Rocas Atoll between 1990 to 2008. The authors observed a high site fidelity for the reproductive females in the Rocas Atoll nesting site, confirming its demographic independence in relation to a close reproductive site (Fernando de Noronha Island, $03^{\circ} 51^{\prime} \mathrm{S} ; 32^{\circ} 25^{\prime} \mathrm{W}$ ).

In the 2019 nesting season, 22 female individuals were sampled in Rocas Atoll, and sampling began as soon as each female initiated the first egg laying. All females had a healthy appearance, i.e. no visible tumours (Jones et al. 2016). During sampling, each female was measured for curved carapace length, from the nuchal notch to the tip of the longest posterior marginal scute $(\mathrm{cm})$, and microchipped for individual identification (to avoid resampling). Two fresh eggs were sampled during the first laying, rinsed in filtered water, and the yolk separated from other egg fractions. The bulk sample with two yolks (from the same female) was stored in a clean transparent plastic bag and kept frozen $\left(-20^{\circ} \mathrm{C}\right)$ until analyses. A carapace fragment $\left(5 \mathrm{~cm}^{2}\right)$ was sampled from the margin of the anterior scute, close to the nuchal notch. Each fragment was immersed in pure acetone to dissolve any incrustation. Then, it was rinsed in filtered water, dried at room temperature, grounded into a homogeneous powder and stored in a clean plastic vial until analyses. The fragment does not represent the oldest tissue in the carapace, as indicated in Lopéz-Castro et al. (2014), but since all samples were collected in the same way, bias is not expected.

\section{Stable isotopes analysis}

One gram of wet weight of yolk (bulk sample) was freeze-dried for 96 hours and ground into a homogeneous powder. Since yolk has a large amount of lipids ( $>50 \%$ in freeze-dried samples) (Carpentier 
et al. 2015), the samples were treated using a 2:1 solvent mixture of chloroform and methanol prior to lipid extraction (Bligh and Dyer 1959). The samples were dried at $60^{\circ} \mathrm{C}$ in an oven for 48 hours to remove the residual solvent. This procedure minimizes bias in $\delta^{13} \mathrm{C}$ data interpretation (Post et al. 2007). Since the extraction of lipids can interfere with the $\delta^{15} \mathrm{~N}$ values (Petitet \& Bugoni 2017); the yolk samples were analyzed twice: with and without lipid extraction. For $\delta^{13} \mathrm{C}$, the mean values in yolk with and without lipid extraction were $-17.9 \pm 1.7 \%$ and $-20.0 \pm 1.7 \%$, respectively; and for $\delta^{15} \mathrm{~N}$ they were $7.2 \pm 1.3 \%$ and $6.9 \pm 1.3 \%$, respectively.

The ratios of stable isotopes were determined in $0.3-0.4 \mathrm{mg}$ of dry weight of each sample (yolk and carapace) using an organic elemental analyzer (Flash 2000, Thermo Scientific) coupled with a mass spectrometer (Delta V Advantage Isotope Ratio Mass Spectrometer, Thermo Scientific) through the ConFlo-VI interface (Model BR30140, Thermo Scientific) in the Laboratório de Ciências Ambientais at Universidade Estadual do Norte Fluminense Darcy Ribeiro. Reference values were Pee Dee Belemnite (PDB) and atmospheric nitrogen. Samples were analyzed using analytical blanks and urea analytical standards (IVA Analysentechnik-330802174). Analytical control was performed for every 10 samples using a certified isotopic standard (Elemental Microanalysis Protein Standard OAS). The reproducibility was based on triplicates for every 10 samples $\left( \pm 0.2 \%\right.$ o, $\delta^{13} \mathrm{C} ; \pm 0.3 \%$, $\left.\delta^{15} \mathrm{~N}\right)$.

\section{Individual niche trajectories}

Individual niche trajectories between isotope values of carapace and yolk quantified the temporal consistency of individual diets (Schmidt et al. 2007; Costa-Pereira et al. 2019). The length of trajectories in the bivariate isotopic space $\left(\delta^{15} \mathrm{~N}-\delta^{13} \mathrm{C}\right)$ was calculated by the Euclidean distance between starting points (carapace) and endpoints (yolk) for each individual. The trajectory direction was determined by the (counter clockwise) angle of the line connecting carapace and yolk values in relation to the $\mathrm{x}$-axis $\left(\delta^{13} \mathrm{C}\right)$. The yolk and carapace are dependent measures because part of the dietary information integrated into one tissue is hierarchically integrated to another tissue. Differences between tissues regarding stable isotope values may emerge by temporal variation in environmental baselines and/or differential isotopic route, and not necessarily due to diet variation over time. Since these potential biases should be homogeneous across individuals, they are not expected to bias the results (Schmidt et al. 2007).

The vectors representing the niche trajectory between carapace and yolk for each green turtle individual in the isotopic space represent a dietary shift from the more general life pattern to the period of vitellogenesis. Differences in the angle of change indicate whether and in which direction individuals' isotopic values shift vertically $\left(\delta^{15} \mathrm{~N}\right.$ or trophic level shift) and/or horizontally $\left(\delta^{13} \mathrm{C}\right.$ or base carbon sources) over time. The magnitude of the diet shift can be measured by the trajectory length. To compare the observed circular distribution of trajectories with the expected null distribution of random changes, we calculated three statistics: mean trajectory length, standard deviation of trajectory length (as a measure of variability) and Rao's spacing statistic $(U)$. The spacing statistic measures the sum of differences of arc-lengths between adjoining points (ranked by angle) and the regularly spaced arc-lengths expected for the null hypothesis of uniformity $(2 \pi / \mathrm{n})$ (Pewsey et al. 2013). The $U$ values become larger as directionality increases, with less deviation between individuals' trajectories. The circular statistics were calculated in the R package circular (Agostinelli \& Lund 2017; R Core Team 2020).

Following the procedure delineated in Costa-Pereira et al. (2019), we used a randomization process to generate stochastic individual niche trajectories in the isotopic space. For each individual, the observed isotopic starting point was kept constant (carapace isotopic values) and the isotopic endpoint was assigned by drawing randomly (without replacement) a pair of yolk isotopic values from the distribution of observed yolk isotope values in the sample of 22 individuals. For each resampling, the endpoint of random trajectories could therefore, assume isotope values observed in the conspecific individuals. The null model tested whether the mean length and standard deviation of observed niche trajectories are compatible with a random expectation, and whether the distribution of trajectory angles support a uniform circular distribution. The null distribution of trajectory statistics was based on 10,000 replicates. Probability values were calculated by the sum of permuted statistics that were equal to or more extreme than the observed, divided by 10,000 . The stable isotope values used in this study, as well as the $\mathrm{R}$ script to calculate trajectory statistics and the randomization procedure are available as Supplementary material.

\section{Results and Discussion}

The multi-tissue isotopes explored the individual trophic consistency of nesting green turtles over the foraging period while individuals stay in the foraging sites (yolk samples), and in a broader temporal scale (carapace samples). Trajectory angles showed directionality towards lighter $\delta^{15} \mathrm{~N}$ values and heavier $\delta^{13} \mathrm{C}$ values (Figure 1). The observed mean and standard deviation of niche trajectory length were smaller than expected by chance $(p<0.0001)$ (Figure 2$)$. The observed sample was more directional than expected under a uniform circular distribution $(\mathrm{U}=176.568, p=0.0083$ ) (Figure 2). The curved carapace length was very homogeneous across the sample $(\mathrm{n}=22$ individuals; $112.5 \pm 5.0$ $\mathrm{cm} ; 107$ to $123 \mathrm{~cm}$ ) and not associated with any isotopic or descriptive variable of the niche trajectory.

The results highlighted that most individuals vary in the consistency of their feeding strategies over time, following a similar pattern. Therefore, a temporal diet shift was noted for the reproductive females that nested at Rocas Atoll during the nesting season of 2019, and this shift was similar within the sample. When the green turtles are in their foraging sites (temporal window measured by the yolk samples), they are more herbivore with stronger association with coastal-benthic waters. Lighter $\delta^{15} \mathrm{~N}$ values represent lower trophic level, typical in herbivore strategy, whereas heavier $\delta^{13} \mathrm{C}$ values are usually associated with coastal-benthic environments (Fry 2008). Conversely, in a broader temporal window, the green turtles demonstrate a carnivore-omnivore strategy, such as represented by heavier $\delta^{15} \mathrm{~N}$ values in the carapace. Heavier $\delta^{15} \mathrm{~N}$ values usually represent a greater contribution of animal matter to the consumer diet (Fry 2008), but they could represent variations in isotopic baseline across turtles' habitat. Different sources of nitrogen in turtles foraging sites influence the isotopic profile of turtles from the same trophic level (Ceriani et al. 2012; Pajuelo et al. 2012). However, if the $\delta^{15} \mathrm{~N}$ values represented the habitat baseline instead of the ingestion of animal matter, we would expect closer $\delta^{15} \mathrm{~N}$ 
Agostinho K.F.F. et al.

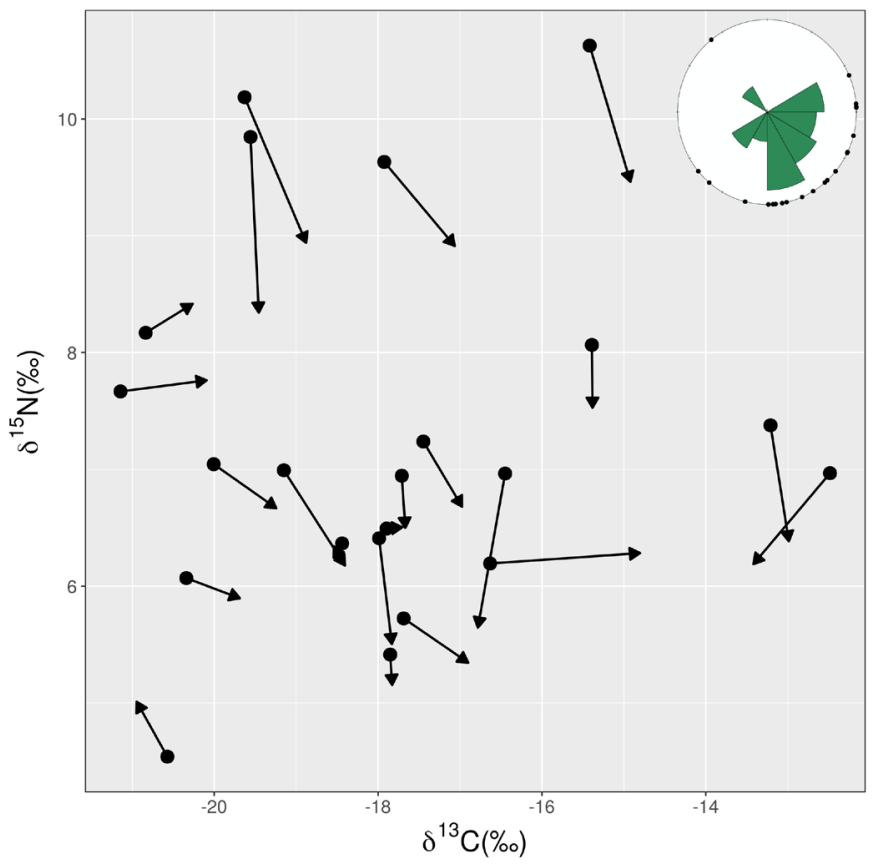

Figure 1. Individual niche trajectories represented by vectors between carapace (black circle) and yolk (black arrow) isotope values, for nesting green turtles on Rocas Atoll, Brazil. The inset represents the observed circular distribution of niche trajectory angles.

values between yolk and carapace in the same turtle, which was noted for only three individuals (Figure 1).

The temporal diet shift demonstrated for the green turtles that nest on Rocas Atoll had a directional pathway, albeit some individual tendencies are noted (Figure 1, Supplementary material). In the four individuals with the highest $\delta^{15} \mathrm{~N}$ values in the carapace ( $>9 \%$ ), both oceanic and coastal foraging habitats are represented $\left(\delta^{13} \mathrm{C}\right.$ range), indicating isotopic enriched in different areas. In three individuals, yolk and carapace samples have similar $\delta^{15} \mathrm{~N}$ values and the temporal diet shift is not evident. Similarities between tissues regarding $\delta^{15} \mathrm{~N}$ values could represent habitat baseline. Individuals from the same population can vary in their foraging strategies over time, while others may have a more constant diet (Bearhop et al. 2004; Martínez del Rio et al. 2009). The nesting populations of sea turtles represent a mix of individuals from several foraging sites, and satellite telemetry reveals high fidelity to specific sites following breeding migrations (Meylan et al. 2011; Shimada et al. 2020). For the green turtle, Shimada et al. (2020) stated high and long-term fidelity to specific foraging sites, with feeding activity also happening during the migration to-and-from the breeding sites. These features support the individual tendencies described above.

Herbivory is recognized as the predominant feeding habit in adult green turtles (Bjorndal 1997; Burgett et al. 2018), but the adult individuals have enough feeding plasticity to take advantage of other food resources when necessary and available, allowing them to behave temporally like carnivores-omnivores (Burkholder et al. 2011). Agostinho et al. (2020) mentioned the possible foraging activity of nesting green turtles while stay at Rocas Atoll for breeding due to the high diversity of food items locally. Indeed, this area is a foraging site for juvenile green and hawksbill turtles (Bellini et al. 2013). The Rocas Atoll biodiversity includes 143 taxa of macroalgae (Villaça et al., 2010) and a range of zoobenthos and fish species (Moraes et al. 2003; Paiva et al. 2007; Batista et al. 2012; Paiva et al. 2015). The higher $\delta^{15} \mathrm{~N}$ values for oceanic habitats (more negative $\delta^{13} \mathrm{C}$ values) noted in two nesting individuals (Figure 1) could be related to the animal matter ingested around the nesting site, that is an oceanic habitat; or even during the migration to-and-from the nesting site.

Figgener et al. (2019) organized an isotopic database for sea turtles species worldwide, demonstrating the variability of isotopic signatures among them, both inter- and intraspecifically, as well as similarities in the isotopic profile. The green turtle is the second most studied species, with $40 \%$ of the available stable isotope studies until November 2018 (Figgener et al. 2019). Meanwhile, data on the isotopic profile of nesting green turtles are still scarce, limited to five studies until the above period (Godley et al. 1998; Hatase et al. 2006; Vander Zanden et al. 2013a; 2013b; Bradshaw et al. 2017). Thus, this study also contributes to the database on $\delta^{13} \mathrm{C}$ and $\delta^{15} \mathrm{~N}$ values in this species (Supplementary material).


Figure 2. Null distributions of niche trajectory statistics: mean and standard deviation of trajectory length, the Euclidean distance between carapace and yolk stable isotope values from a given green turtle individual, and Rao's spacing statistic, quantifying the degree of directionality in niche trajectories. Red vertical lines indicate observed values. 
Despite the small sample size $(n=22)$, the isotopic niche trajectories had strong statistical support to demonstrate the temporal diet shift for most green turtle individuals that nest on Rocas Atoll, off northeastern Brazil, during 2019 nesting season. To our knowledge, this is the first study that presents this approach for sea turtles, adding a new isotopic tool to understand the trophic ecology of these migrant animals. This approach has potential to be applied in other green turtle populations and/or in other sea turtle species. Since the adult green turtles can feed in the full extent of the habitat (foraging sites, breeding sites and to-and-from), changes in the food availability in these sites and over their migratory routes might compromise the health of the reproductive population. In a global scenario of rapid environmental changes, it deserves concern because sea turtles are long-lived endangered animals, and most species, like the green turtles, have high site fidelity for both feeding and breeding sites.

\section{Supplementary Material}

The following online material is available for this article:

Stable isotopes data of nesting green turtles on Rocas Atoll, Brazil (2019 nesting season)

\section{Acknowledgments}

We are indebted to Dr. Marcelo Gomes de Almeida for the stable isotopes analysis, to Jarian Dantas for helping during field activities and to Maurizélia de Brito Silva, coordinator of Biological Reserve of Rocas Atoll, for logistic support in the field campaigns. The Instituto Chico Mendes de Conservação da Biodiversidade (ICMBio), Fundação SOS Mata Atlântica and FUNBIO/Banco Mundial (GEFMAR project) support the field campaigns. The Conselho Nacional de Desenvolvimento Científico e Tecnológico - CNPq (grant 301.259/2017-8), Fundação Carlos Chagas Filho de Amparo à Pesquisa do Estado do Rio de Janeiro - FAPERJ (grants E-26/202.770/2017, E-26/210.883/2016 and E-26/210.064/2018) and Coordenação de Aperfeiçoamento de Pessoal de Nível Superior - CAPES (Finance Code 001) contribute with financial support.

\section{Author Contributions}

Karoline Fernanda Ferreira Agostinho: sampling, methodology.

Leandro Rabello Monteiro: formal analysis, writing - review \& editing.

Ana Paula Madeira Di Beneditto: funding acquisition, conceptualization, investigation, writing - original draft, writing review \& editing.

\section{Conflicts of Interest}

The authors declare that they have no conflict of interest related to the publication of this manuscript.

\section{References}

AGOSTINELLI, C. \& LUND, U. 2017. R package "circular": Circular Statistics (version 0.4-93). URL https://r-forge.r-project.org/projects/circular/URL https://r-
AGOSTINHO, K.F.F., LACERDA, D., TOSTES, E.C.L., BALDASSIN, P., DI BENEDITTO, A.P.M. \& CARVALHO, C.E.V. 2020. Trace elements in green turtles (Chelonia mydas) from Rocas Atoll, NE Brazil: Baseline reference from a pristine nesting site. Mar. Poll. Bull. 157: 111271.

AUERSWALD, K., WITTMER, M.H.O., ZAZZO, A., SCHÄUFELE, R. \& SCHNYDER, H. 2010. Biases in the analysis of stable isotope discrimination in food webs. J. Appl. Ecol. 47:936-941.

BEARHOP, S., ADAMS, C.E., WALDRON, S., FULLER, R.A. \& MACLEOD, H. 2004. Determining trophic niche width: A novel approach using stable isotope analysis. J. Animal. Ecol. 73:1007-1012.

BATISTA, H., ZILL, J., VERAS, D., HAZIN, F., OLIVEIRA, P., MARINS, Y., OLIVEIRA, D., PEREIRA, R., TOLOTTI, M. \& SILVA, M. 2012. New records of reef fishes (Teleostei: Perciformes) in the Rocas Atoll Biological Reserve, off northeastern Brazil. Check List 8: 584-588.

BELLINI, C., SANTOS, A.J., GROSSMAN, A., MARCOVALDI, M.A. \& BARATA, P.C. 2013. Green turtle (Chelonia mydas) nesting on Atol das Rocas, north-eastern Brazil, 1990-2008. J. Mar. Biol. Assoc. UK 93:11171132 .

BJORNDAL, K.A. 1997. Foraging ecology and nutrition of sea turtles. In The biology of sea turtles (P.L. Lutz \& J.A. Musick, eds.). CRC Press, Boca Raton, p.199-231.

BLIGH, E.G. \& DYER, W.J. 1959. A rapid method of total lipid extraction and purification. Can. J. Biochem. Physiol. 37: 911-917.

BRADSHAW, P.J., BRODERICK, A.C., CARRERAS, C., INGER, R., FULLER, W., SNAPE, R., STOKES, K.L. \& GODLEY, B.J. 2017. Satellite tracking and stable isotope analysis highlight differential recruitment among foraging areas in green turtles. Mar. Ecol. Prog. Ser. 582: 201-214.

BURGETT, C.M., BURKHOLDER, D.A., COATES, K.A., FOURQUREAN, V.L., KENWORTHY, W.J., MANUEL, S.A., OUTERBRIDGE, M.E. \& FOURQUREAN, J.W. 2018. Ontogenetic diet shifts of green sea turtles (Chelonia mydas) in a mid-ocean developmental habitat. Mar. Biol. 165:33.

BURKHOLDER, D.A., HEITHAUS, M.R., THOMSON, J.A. \& FOURQUREAN, J.W. 2011. Diversity in trophic interactions of green sea turtles Chelonia mydas on a relatively pristine coastal foraging ground. Mar. Ecol. Prog. Ser. 439: 277-293.

CARMAN, V.G., FALABELlA, V., MAXWELL, S., ALBAREDA, D., CAMPAGNA, C. \& MIANZAN, H. 2012. Revisiting the ontogenetic shift paradigm: The case of juvenile green turtles in the SW Atlantic. J. Exp. Mar. Biol. Ecol. 429: 64-72.

CARPENTIER, A.S., BOOTH, D.T., ARTHUR, K.E. \& LIMPUS, C.J. 2015 Stable isotope relationships between mothers, eggs and hatchlings in loggerhead sea turtles Caretta caretta. Mar. Biol. 162: 783-797.

CERIANI S.A., ROTH, J.D., EVANS, D.R., WEISHAMPEL, J.F. \& EHRHART, L.M. 2012. Inferring foraging areas of nesting loggerhead turtles using satellite telemetry and stable isotopes. Plos One 7: e45335.

COSTA-PEREIRA, R., TOSCANO, B., SOUZA, F.L., INGRAM, T. \& ARAÚJO, M.S. 2019. Individual niche trajectories drive fitness variation. Funct. Ecol. 33: 1734-1745.

DI BENEDITTO, A.P.M., SICILIANO, S. \& MONTEIRO, L.R. 2017. Herbivory level and niche breadth of juvenile green turtles (Chelonia mydas) in a tropical coastal area: insights from stable isotopes. Mar. Biol. 164: 13

FIGGENER, C., BERNARDO, J. \& PLOTKIN, P.T. 2019. Data from: MarTurtSI, a global database of stable isotope analyses of marine turtles. Sci. Data 6: 16

FRY, B. 2008. Stable Isotope Ecology. Springer Science Business Media, New York, $316 \mathrm{p}$.

FUKUOKA, T., NARAZAKI, T., KINOSHITA, C. \& SATO, K. 2019. Diverse foraging habits of juvenile green turtles (Chelonia mydas) in a summerrestricted foraging habitat in the northwest Pacific Ocean. Mar. Biol. 166: 25

GODLEY, B.J., THOMPSON, D.R., WALDRON, S. \& FURNESS, R.W. 1998. The trophic status of marine turtles as determined by stable isotope analysis. Mar. Ecol. Prog. Ser. 166: 277-284.

HATASE, H., SATO, K., YAMAGUCHI, M., TAKAHASHI, K. \& TSUKAMOTO, K. 2006. Individual variation in feeding habitat use by adult female green sea turtles (Chelonia mydas): are they obligately neritic herbivores? Oecologia 149: 52-64. 
Agostinho K.F.F. et al.

HOBSON, K. 1999. Tracing origins and migration of wildlife using stable isotopes: a review. Oecologia 120: 314-326.

JONES, K. ARIEL, E., BURGESS, G. \& READ, M. 2016. A review of fibropapillomatosis in green turtles (Chelonia mydas). Vet. J. 212: 48-57.

LÓPEZ-CASTRO, M.C., BJORNDAL, K.A. \& BOLTEN, A.B. 2014. Evaluation of scute thickness to infer life history records in the carapace of green and loggerhead turtles. Endang. Species Res. 24: 191-196.

MARTÍNEZ DEL RIO, C., SABAT, P., ANDERSON-SPRECHER, R. \& GONZALEZ, S.P. 2009. Dietary and isotopic specialization: the isotopic niche of three Cinclodes ovenbirds. Oecologia 161: 149-159.

MEYLAN, P.A., MEYLAN, A.B. \& GRAY, J.A. 2011. The ecology and migrations of sea turtles. 8. Tests of the developmental habitat hypothesis. Bull. Am. Mus. Nat. Hist. 357: 1-70.

MORAES, F.C., VILANOVA, E.P. \& MURICY, G. 2003. Distribuição das esponjas (Porifera) na Reserva Biológica do Atol das Rocas, nordeste do Brasil Arq. Mus. Nac. 61: 13-22.

NEWSOME, S.D., MARTINEZ DEL RIO, C., BEARHOP, S. \& PHILLIP, D.L. 2007. A niche for isotopic ecology. Front. Ecol. Environ. 5: 429-436.

PAIVA, P.C., YOUNG, P.S. \& ECHEVERRÍA, CA. 2007. The Rocas Atoll, Brazil: a preliminary survey of the Crustacea and Polychaete fauna. Arq Mus Nac 65:241-250

PAIVA, S.V., OLIVEIRA FILHO, R.R. \& LOTUFO, T.M.C. 2015. Ascidians from Rocas Atoll, northeast Brazil. Front. Mar. Sci. 2: 39.

PAJUELO, M., BJORNDAL, K., REICH, K., ARENDT, M. \& BOLTEN, A. 2012. Distribution of foraging habitats of male loggerhead turtles (Caretta caretta) as revealed by stable isotopes and satellite telemetry. Mar. Biol. 159. https://doi.org/10.1007/s00227-012-1906-9.

PETITET, R. \& BUGONI, L. 2017. High habitat use plasticity by female olive ridley sea turtles (Lepidochelys olivacea) revealed by stable isotope analysis in multiple tissues. Mar. Biol. 164: 134.

PEWSEY, A., NEUHAUSER, M. \& RUXTON, G.D. 2013. Circular statistics in R. Oxford University Press, Oxford, 192 p.

POST, D.M., LAYMAN, C.A., ARRINGTON, D.A., TAKIMOTO, G., QUATTROCHI, J. \& MONTAÑA, C.G. 2007. Getting to the fat of the matter: models, methods and assumptions for dealing with lipids in stable isotope analyses. Oecologia 152: 179-189.
$R$ CORE TEAM. 2020. R: A language and environment for statistical computing. R Foundation for Statistical Computing, Vienna, Austria. https://www.R-project.org/

ROSTAL, D.C., OWENS, D.W., GRUMBLES, J.S., MACKENZIE, D.S. \& AMOSS Jr, M.S. 1998. Seasonal reproductive cycle of the Kemp's ridley sea turtle (Lepidochelys kempi). Gen. Comp. Endocrinol. 109: 232-243.

SHIMADA, T., LIMPUS, C.J., HAMANN, M., BELL, I., ESTEBAN, N., GROOM, R. \& HAYS, G.C. 2020. Fidelity to foraging sites after long migrations. J. Anim. Ecol. 8: 1008-1016.

SCHMIDT, S.N., OLDEN, J.D., SOLOMON, C.T. \& VANDER ZANDEN, M.J.V. 2007. Quantitative approaches to the analysis of stable isotope food web data. Ecology 88: 2793-2802.

VANDER ZANDEN, H.B., ARTHUR, K.E., BOLTEN, A.B., POPP, B.N., LAGUEUX, C.J., HARRISON, E., CAMPBELL, C.L. \& BJORNDAL, K.A. 2013a. Trophic ecology of a green turtle breeding population. Mar. Ecol. Prog. Ser. 476: 237-249.

VANDER ZANDEN, H.B., BJORNDAL, K.A. \& BOLTEN, A.B. 2013b. Temporal consistency and individual specialization in resource use by green turtles in successive life stages. Oecologia 173: 767-777.

VELÉZ-RUBIO, G.M., CARDONA, L., LÓPEZ-MENDILAHARSU, M., MARTÍNEZ SOUZA, G., CARRANZA, A., GONZÁLEZ-PAREDES, D. \& TOMÁS, J. 2016. Ontogenetic dietary changes of green turtles (Chelonia mydas) in the temperate southwestern Atlantic. Mar. Biol. 163: 57.

VILLAÇA, R., FONSECA, A.C., JENSEN, V.K. \& KNOPPERS, B. 2010. Species composition and distribution of macroalgae on Atol das Rocas, Brazil, SW Atlantic. Botan. Marin. 53: 113-122.

Received: 06/08/2020

Revised: 19/10/2020

Accepted: 09/11/2020

Published online: 14/12/2020 